Crop Breeding and Applied Biotechnology 15: 112-116, 2015

Brazilian Society of Plant Breeding. Printed in Brazil

NOTE

http://dx.doi.org/10.1590/1984-70332015v15n2n20

\title{
Global DNA methylation changes in Cucurbitaceae inter-species grafting
}

Evangelia Avramidou ${ }^{1,4}$, Aliki Kapazoglou'2, Filippos A. Aravanopoulos ${ }^{1}$, Aliki Xanthopoulou ${ }^{2}$, Ioannis Ganopoulos ${ }^{2}$, Aphrodite Tsaballa ${ }^{2}$, Panagiotis Madesis ${ }^{2}$, Andreas G. Doulis ${ }^{4 *}$ and Athanasios Tsaftaris ${ }^{2,3}$

Received 27 August 2014

Accepted 28 October 2014

\begin{abstract}
Grafting has been used to improve yield, fruit quality and disease resistance in a range of tree and vegetable species. The molecular mechanisms underpinning grafting responses have only recently started to be delineated. One of those mechanisms involves long distance transfer of genetic material from rootstock to scion alluding to an epigenetic component to the grafting process. In the research presented herein we extended published work on heritable changes in the DNA methylation pattern of Solanaceae scion genomes, in Cucurbitaceae inter-species grafting. Specifically, we examined global DNA methylation changes in scions of cucumber, melon and watermelon heterografted onto pumpkin rootstocks using MSAP analysis. We observed a significant increase of global DNA methylation in cucumber and melon scions pointing to an epigenetic effect in Cucurbitaceae heterografting. Exploitation of differential epigenetic marking in different rootstock-scion combinations could lead to development of epi-molecular markers for generation and selection of superior quality grafted vegetables.
\end{abstract}

Key words: DNA methylation, epigenetic regulation, epigenetic breeding, grafting, Cucurbitaceae.

\section{INTRODUCTION}

Grafting is an ancient agricultural practice that has been used extensively for more than 2000 years worldwide. The purpose of grafting is to produce high quality plants by combining favorable characteristics of the two graft partners, the rootstock and the recipient scion. Beneficial rootstocks can provide resistance to pests and pathogens and increase tolerance to environmental stressful conditions such as temperature changes, increased salinity and heavy metal soil composition (Tomaz et al. 2002, King et al. 2008, Colla et al. 2010). Grafting was first applied to woody species and presently commercial tree and nut tree production relies heavily on grafting for higher yields and disease resistance (Kubota et al. 2008).

In vegetable production grafting has been used widely within the Solanaceae and Cucurbitaceae in order to cope with soil-borne infections and provide enhanced abiotic stress tolerance (Kubota et al. 2008, Lee et al. 2010, Savvas et al. 2010, Schwarz et al. 2010). A wealth of reports have illustrated that different rootstock genotypes could have differential effects on the yield and quality of the grafted vegetable and the overall performance of the graft largely depends on the specificity of the rootstock-scion combination (Cohen et al. 2007, Davis et al. 2008).

In the past decade, a growing number of investigations in Cucurbitaceae grafting has been carried out aiming to improve the performance of high-value vegetables such as cucumber, melon and watermelon (Cohen et al. 2007). Recently, grafting of watermelon onto specific rootstocks resulted in significant increase of lycopene content in watermelon fruits and enhanced resistance to soil-borne diseases (Mohamed et al. 2012), whereas different rootstock-scion combinations lead to alterations in the content of plant nutrients in leaves and fruits of watermelon grafts (Yetisir et al. 2013). In addition, cucumber and melon grafted onto pumpkin rootstocks were shown to exhibit enhanced tolerance to increased salinity (Huang et al. 2013, Orsini et al. 2013).

The interaction between the two graft partners involves

\footnotetext{
${ }^{1}$ Aristotle University of Thessaloniki, Faculty of Forestry and Natural Environment, Laboratory of Forest Genetics and Tree Breeding, Greece, GR-54124

${ }^{2}$ Institute of Applied Biosciences (INAB), CERTH, Thermi-Thessaloniki, GR-57001, Greece

${ }^{3}$ Aristotle University of Thessaloniki, Department of Genetics and Plant Breeding, Thessaloniki, GR-54124, Greece

${ }^{4}$ Hellenic Agricultural Organization DEMETER-NAGREF, Institute of Viticulture, Floriculture \& Vegetable Crops, Heraklion, Crete, GR-71003, Greece.

* Email: andreas.doulis@nagref-her.gr
} 
transport of biological molecules like nutrients, hormones, proteins and genetic material across the graft union. Several studies in Arabidopsis, tomato and cucurbits, have demonstrated long-distance movement of small non-coding RNAs, microRNAs (miRNAs) and small-interfering RNAs (siRNAs), from the rootstock to the scion, in homografted and heterografted plants (Haroldsen et al. 2013). Small non coding RNAs, siRNAs, are known to direct RNA-dependent DNA methylation (RdDM) leading to transcriptional gene silencing (TGS) (Zhang and Zhu 2011), a phenomenon that recently has been observed in both partners in grafted plants. An siRNA molecule originating from a rootstock transgene was shown to move across the graft union to the scion part in Arabidopsis homografts (Molnar et al. 2010). Notably, the transgene-derived siRNA mediated gene silencing in the root part of the graft. In addition, a $24 \mathrm{nt}$ endogenously derived siRNA was translocated to the scion and directed DNA methylation in the genome of scion recipient cells (Molnar et al. 2010). Similarly, in tobacco homografts, a transgene siRNA directed rootstock DNA methylation and after transport through the graft union it mediated silencing of the transgene in the scion (Bai et al. 2011).

Epigenetic changes such as DNA methylation can lead to gene activation or gene silencing associated with critical cellular functions which may take place during the grafting process and in the grafted plant (Law and Jacobsen 2010, Tsaftaris et al. 2012, Tsaballa et al. 2013). Epigenetic changes induced by grafting may provide a new source of variation underlying novel traits with implications in modern breeding.

Very recently it was shown that reciprocal interspecies grafting in three Solanaceae species, induced significant DNA methylation alterations in the genomes of tomato, eggplant and pepper scions. Moreover, the graft-induced DNA methylation changes were found to be heritable to

Table 1. Sequences of adapters for the EcoRI and HpaII/MspI ligation step, and for the pre-selective (EcoRI+1, HpaII/MspI+1) and selective $(E c o R I+3, \mathrm{HpaII} / M s p I+3)$ amplifications

\begin{tabular}{lc}
\hline Primers/Adapters & Sequences 5'_-> 3' \\
\hline EcoRI adapter & CTCGTAGACTGCGTACC \\
EcoRI+1 & AATTGGTACGCAGTC \\
EcoRI+3 & GACTGCGTACCAATTC+A \\
& + ATG \\
& + ACT \\
& + AAC \\
HpaII/MspI adapter & + AAG \\
& GACGATGAGTCTCGAT \\
HpaII/MspI + 1 & CGATCGAGACTCAT \\
HpaII/MspI + 3 & ATGAGTCTCGATCGG+T \\
\hline
\end{tabular}

the self-pollinated progeny (Wu et al. 2013).

In the present study we extended these investigations to the as yet unexplored molecular mechanisms of grafting in Cucurbitaceae. We have investigated grafting of three species, cucumber, watermelon and melon and methylation changes that occurred, by using Methylation Sensitive Amplification Polymorphism (MSAP) analyses, which can identify and estimate susceptible anonymous 5'-CCGG sequences and access their methylation status. The MSAP method uses two pairs of isoschizomers EcoRI/HpaII and EcoRI/MspI that have different sensitivity to methylation at the inner or outer cytosine. Differences in the products from the two different treatments obtained reflect different methylation states at the cytosines. We have demonstrated for the first time alterations in the DNA methylation pattern of the Cucurbitaceae scion genomes.

\section{MATERIAL AND METHODS}

\section{Plant materials}

Pure line cultivars or $\mathrm{F}_{1}$ hybrids of three species of Cucurbitaceae, cucumber (Cucumis sativus) cv. Skotinos, melon (Cucumis melo) cv. Fanis-3, watermelon (Citrullus lanatus) cv. Obla, designated as $\mathrm{C}, \mathrm{M}$, and $\mathrm{W}$, respectively, were used in this study. Squash hybrid 'TZ-148' was used as the rootstock for all three species.

\section{Grafting and material sampling}

Grafting was performed according to Tsaballa et al. (2013). Grafts were maintained and gradually hardened in the greenhouse for about two weeks when the unions were strengthened and plants reached the 8-10-leaf stage. Leaf materials collected from the graft part were used for the MSAP analysis while leaf materials originating from the

Table 2. Molecular basis of MSAP. Isoschizomers HpaII/MspI recognize the same restriction 5'-CCGG site but have different sensitivity to methylation of the cytosines

\begin{tabular}{|c|c|c|c|c|c|c|}
\hline Hра II & $M s p$ I & Sign & & & & \\
\hline \multirow{2}{*}{1} & \multirow{2}{*}{1} & \multirow{2}{*}{ Unmethylated } & $\mathrm{C}$ & $\mathrm{C}$ & G & $\mathrm{G}$ \\
\hline & & & G & G & $\mathrm{C}$ & $\mathrm{C}$ \\
\hline \multirow{4}{*}{1} & \multirow{4}{*}{0} & \multirow{4}{*}{ CHG } & $\mathrm{C}$ & $\mathrm{C}$ & $\mathrm{C}$ & $\mathrm{G}$ \\
\hline & & & C & $\mathrm{C}$ & G & $\mathrm{G}$ \\
\hline & & & C & $\mathrm{C}$ & G & $\mathrm{G}$ \\
\hline & & & $\mathrm{G}$ & $\mathrm{G}$ & $\mathrm{C}$ & $\mathrm{C}$ \\
\hline \multirow{2}{*}{0} & \multirow{2}{*}{1} & \multirow{2}{*}{ CG } & $\mathrm{C}$ & C & $\mathrm{G}$ & $\mathrm{G}$ \\
\hline & & & $\mathrm{C}$ & $\mathrm{C}$ & G & $\mathrm{G}$ \\
\hline
\end{tabular}

1 defines the digestion and $\mathrm{C}$ defines the methylcytosine 
same $F_{1}$ hybrids of non-grafted plants served as respective controls. Each plant material treatment (grafted or seededcontrol) combination consisted of three independent samples.

\section{MSAP analysis}

MSAP analysis was performed according to $\mathrm{Wu}$ et al. (2013). Briefly, genomic DNA(200 ng) was double-digested with EcoRI/HpaII and EcoRI/MspI, followed by ligation of two different adapters and a pre-amplification reaction. Diluted pre-amplified fragments were used as starting material for selective amplification with selected primers (Table 1).

Fragment separation and detection from selective amplification was made by using an ABI PRISM 3730x1 DNA sequencer. Genemapper 4.0 (Applied Biosystems) was used for scoring MSAP fragments (Table 2) and provided a matrix where alleles are presented with " 1 " (presence of fragment) and with " 0 " (absence of fragment). The local Southern method was used for auto sizing with the following specifications: baseline window 51 pts, analysis range 50700 base-pairs and bin-width 0.5 . Peak quality and Quality flags was used as default for the analysis. Statistical analysis was performed according to Wu et al. (2013).

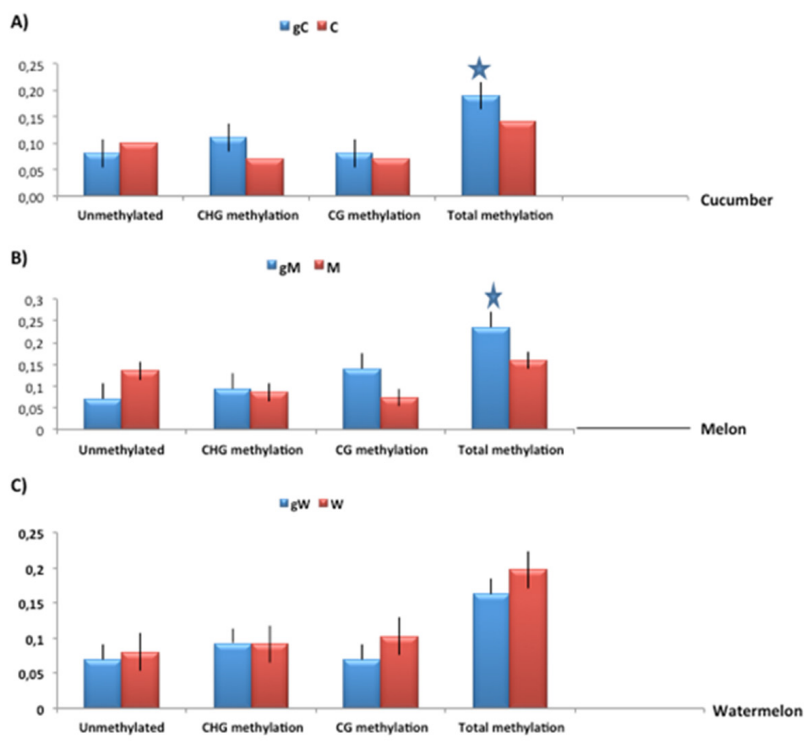

Figure 1. Relative methylation/non-methylation levels based on MSAP analysis in grafted plants and seed-plant controls. A) cucumber-pumpkin graft. B) melon-pumpkin graft. C) watermelon-pumpkin graft. CHG, CG and unmethylated sites indicate hemi-methylation, full methylation and no methylation, respectively. Pooled leaves from three independent scion/ rootstock plants were analyzed for each species. Data represent mean values from three technical repeats for each biological sample (three plants). Values significantly different from the control are marked with an asterisk $(*)$. $\mathrm{gC}$, grafted cucumber; $\mathrm{gM}$, grafted melon; $\mathrm{gW}$, grafted watermelon. C, cucumber seed-plant control; M, melon seed-plant control; $\mathrm{W}$, watermelon seed-plant control.

\section{RESULTS AND DISCUSSION}

Grafting of three Cucurbitaceae species, in particular, cucumber (Cucumis sativus), melon (Cucumis melo), and watermelon (Citrullus lanatus), were carried out onto pumpkin rootstocks (squash hybrid TZ148). When scions of heterografts reached the 8-leaf stage, leaf material was harvested for further analysis. MSAP analysis was used to determine the DNA methylation pattern at 5'-CCGG-3' sites by scoring the presence or absence of bands after EcoRI/HpaII and EcoRI/MspI digestion of genomic DNA and subsequent PCR amplification. Three individual scion-rootstock grafted plants for each species were used for the experiment. Since the cucumber, melon, and watermelon cultivars examined represent pure lines, only one seed-plant was used as the non-grafted control for each cultivar. Based on the MSAP profiles the numbers of nonmethylated, hemi-methylated

A)

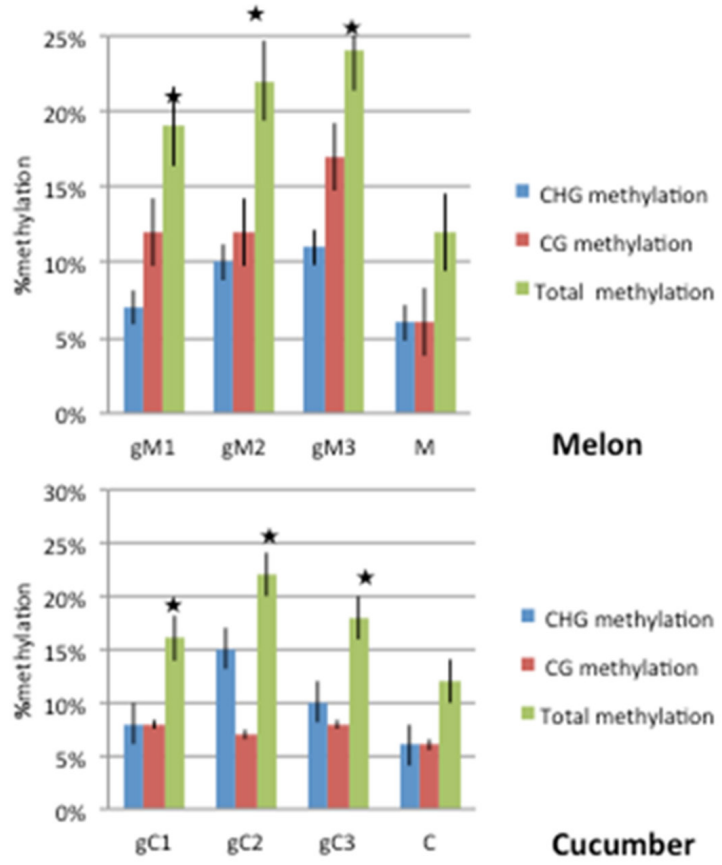

C)

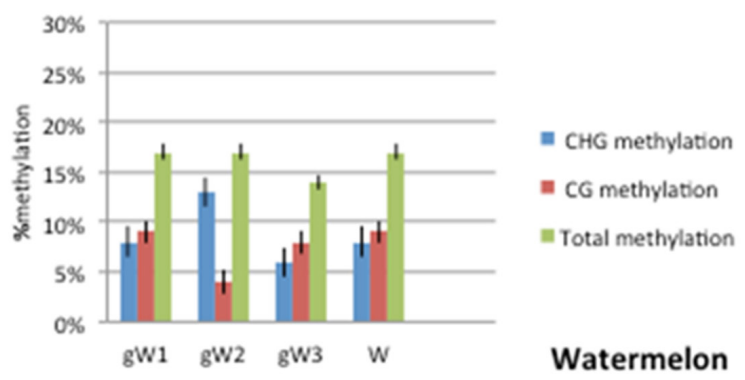

Figure 2. Tabulated data of alteration in DNA methylation patterns based on the MSAP analysis. 
(CHG) and fully-methylated (CG) sites were calculated. Mean methylation levels of three cucumber/pumpkin grafts displayed significant increase in the $\mathrm{CHG}$ context $(\sim 1.8$ fold) and $\sim 1.2$ fold in total methylation, whereas levels were unaltered in CG methylation, compared to the seedplant control (Figure 1A). Mean methylation levels of three melon/pumpkin graft also exhibited a significant induction in the CG methylation of $\sim 2.0$ fold and in total methylation of $\sim 1.25$ fold, whereas levels were only slightly increased in CHG methylation, compared to the melon seed-plant control (Figure 1B).

Significant methylation changes were not observed for the watermelon/pumpkin grafted plants (Figure 1C). DNA methylation levels were also calculated for each one of three individual plants from each specific graft. These are shown along with their controls ( $\mathrm{C}, \mathrm{M}$, and $\mathrm{W}$, respectively) in Figure 2. Homografts were not included in this study, as it was well established in the recent study by Wu et al. (2013) that significant DNA methylation changes did not occur in homografted Solenaceae plants.

In the current study we have demonstrated global DNA methylation alterations in scions of cucumber, melon and watermelon grafted onto pumpkin rootstocks. A change in the level of an epigenetic mark in the genome of cucurbit scions is in agreement with previous reports showing changes in the DNA methylation pattern in scions of three heterografted Solanaceae species (Wu et al. 2013).
Epigenetic modifications such as DNA methylation and histone modifications are known to lead to changes in chromatin structure. Open and closed chromatin states are associated with gene activation and gene silencing, respectively, and govern proper onset of gene expression programmes during development and in response to changing environmental conditions (Bennetzen and Zhu 2011). Locus-specific and mainly genome-wide studies analyzing entire methylomes have well established that DNA methylation depends on a number of endogenous and exogenous factors including genotype, cell type, developmental stage and environmental stimulus (Cokus et al. 2008, Feng et al. 2010, Karan et al. 2012, Li et al. 2012, Song et al. 2012, Zhong et al. 2013). Since grafting engages most of these factors it is conceivable that DNA methylation changes will be evidenced in the grafting partners, that is, the rootstock and the scion of grafted plants.

The data presented above serve as a basis for exploring further Cucurbitaceae grafting. In addition, this information will contribute to a better understanding of the molecular mechanisms underlying the grafting process and epigenetic regulation in grafted plants. Hence, development of rapid and low-cost methods detecting not only genetic variation but also epigenetic variation will provide an invaluable new tool much needed in current crop breeding technologies and in the analysis of crop wild relatives.

\title{
Mudanças na metilação de DNA global em enxertia interespecífica com Cucurbitaceae
}

\begin{abstract}
Resumo - Enxertia é usada no melhoramento da produção, da qualidade do fruto e na resistência 'a doenças em espécies vegetais arbóreas. Os mecanismos moleculares sobre as respostas à enxertia estão sendo delineados somente agora. Um deles envolve a transferência a longa distância de material genético do porta-enxerto ao enxerto, aludindo a um componente epigenético para o processo de enxertia. Nesta pesquisa foram investigadas as mudanças herdáveis no padrão de metilação de DNA de genomas de enxertos de solanaceae, em enxertia interespecifica com Cucurbitaceae. As mudanças na metilação de DNA global em enxertos de pepino, melão e melancia, heteroenxertados em porta-enxertos de moranga, foram examinadas usando análise MSAP. Ocorreu incremento significativo de metilação de DNA em pepino e melão, apontando para um efeito epigenético em Cucurbitaceae heteroenxertadas. A exploração do marcador epigenético diferencial em diferentes combinações de porta-enxertos/enxertos pode levar ao desenvolvimento de marcas epimoleculares para geração e seleção de vegetais enxertados de qualidade superior.
\end{abstract}

Key words: Metilação de DNA, regulação epigenética, melhoramento epigenético, enxertia, Cucurbitaceae.

\section{REFERENCES}

Bai S, Kasai A, Yamada K, Li T and Harada T (2011) A mobile signal transported over a long distance induces systemic transcriptional gene silencing in a grafted partner. Journal of Experimental Botany 62: 4561-4570.

Bennetzen JL and Zhu JK (2011) Epigenetics of the epigenome. Current Opinion in Plant Biology 14: 113-115.

Cohen R, Burger Y, Horev C, Koren A and Edelstein M (2007) Introducing grafted cucurbits to modern agriculture: the Israeli experience. Plant Disease 91: 916-923.

Cokus S, Feng S, Zhang X, Chen Z, Merriman B, Haudenschild C, Pradhan S, Nelson S, Pellegrini M and Jacobsen S (2008) Shotgun bisulphite sequencing of the Arabidopsis genome reveals DNA methylation patterning. Nature 452: 215-219.

Colla G, Rouphael Y, Leonardi C and Bie Z (2010) Role of grafting in vegetable crops grown under saline conditions. Scientia Horticulturae 127: 147-155. 
E Avramidou et al.

Davis AR, Perkins-Veazie P, Hassell R, Levi A, King SR, Zhang X (2008) Grafting effects on vegetable quality. HortScience 43: 1670-1672.

Feng S, Jacobsen SE and Reik W (2010) Epigenetic reprogramming in plant and animal development. Science 330: 622-627.

Haroldsen V, Szczerba MW, Aktas H, Lopez J, Odias MJ, Chi-Ham CL, Labavitch J, Bennett AB and Powell ALT (2013) Delivery of nucleic acids and proteins from grafted rootstocks for pathogen and pest control. Frontiers in Plant Science 3: 1-12.

Huang Y, Bie Z, Liu P, Niu M, Zhen A, Liu Z, Lei B, Gu D, Lu C and Wang B (2013) Reciprocal grafting between cucumber and pumpkin demonstrates the roles of the rootstock in the determination of cucumber salt tolerance and sodium accumulation. Scientia Horticulturae 149: 47-54.

Karan R, DeLeon T, Biradar H and Subudhi PK (2012) Salt stress induced variation in DNA methylation pattern and its influence on gene expression in contrasting rice genotypes. PLoS ONE 7: e40203.

King SR, Davis AR, Liu W and Levi A (2008) Grafting for disease resistance. HortScience 43: 1673-1676.

Kubota C, McClure MA, Kokalis-Burelle N, Bausher MG and Rosskopf EN (2008) Vegetable grafting: history, use, and current technology status in North America. HortScience 43: 1664-1669.

Law JA and Jacobsen SE (2010) Establishing, maintaining and modifying DNA methylation patterns in plants and animals. Nature Reviews Genetics 11: 204-220.

Lee J-M, Kubota C, Tsao SJ, Bie Z, Echevarria PH, Morra L and Oda M (2010) Current status of vegetable grafting: Diffusion, grafting techniques, automation. Scientia Horticulturae 127: 93-105.

Li X, Zhu J, Hu F, Ge S, Ye M, Xiang H, Zhang G, Zheng X, Zhang H, Zhang S, Li Q, Luo R, Yu C, Yu J, Sun J, Zou X, Cao X, Xie X, Wang J and Wang W (2012) Single-base resolution maps of cultivated and wild rice methylomes and regulatory roles of DNA methylation in plant gene expression. BMC Genomics 13: 300.

Mohamed F, El-Hamed K, Elwan M and Hussien MA (2012) Impact of grafting on watermelon growth, fruit yield and quality. Vegetable Crops Research Bulletin 76: 99-118.

Molnar A, Melnyk CW, Bassett A, Hardcastle TJ, Dunn R and Baulcombe DC (2010) Small silencing RNAs in plants are mobile and direct epigenetic modification in recipient cells. Science 328: 872-875.
Orsini F, Sanoubar R, Oztekin GB, Kappel N, Tepecik M, Quacquarelli C, Tuzel Y, Bona S and Gianquinto G (2013) Improved stomatal regulation and ion partitioning boosts salt tolerance in grafted melon. Functional Plant Biology 40: 628-636.

Savvas D, Colla G, Rouphael Y and Schwarz D (2010) Amelioration of heavy metal and nutrient stress in fruit vegetables by grafting. Scientia Horticulturae 127:156-161.

Schwarz D, Rouphael Y, Colla G and Venema JH (2010) Grafting as a tool to improve tolerance of vegetables to abiotic stresses: Thermal stress, water stress and organic pollutants. Scientia Horticulturae 127: 162-171.

Song Y, Ji D, Li S, Wang P, Li Q and Xiang F (2012) The dynamic changes of DNA methylation and histone modifications of salt responsive transcription factor genes in soybean. PLoS ONE 7: e41274.

Tomaz MA, Sakiyama NS, Martinez HEP, Cruz CD, Zambolim L and Pereira AA (2002) Grafted young coffee tree growth in a greenhouse. Crop Breeding and Applied Biotechnology 2: 425-430.

Tsaballa A, Athanasiadis C, Pasentsis K, Ganopoulos I, Nianiou-Obeidat I and Tsaftaris A (2013) Molecular studies of inheritable grafting induced changes in pepper (Capsicum annuum) fruit shape. Scientia Horticulturae 149: 2-8.

Tsaftaris AS, Kapazoglou A and Darzentas N (2012) From epigenetics to epigenomics and their implications in plant breeding. In Altman A and Hasagawa PM (Eds) Plant biotechnology and agriculture: Prospects for the 21st century. Academic Press, New York, p. 207-226.

Wu R, Wang X, Lin Y, Ma Y, Liu G, Yu X, Zhong S and Liu B (2013) Inter-species grafting caused extensive and heritable alterations of DNA methylation in Solanaceae Plants. PLoS ONE 8: e61995.

Yetisir H, Özdemir E, Aras V, Candır E and Aslan H (2013) Rootstocks effect on plant nutrition concentration in different organ of grafted watermelon Agricultural Sciences 4: 230-237.

Zhang H and Zhu J-K (2011) RNA-directed DNA methylation. Current Opinion in Plant Biology 14: 142-147.

Zhong S, Fei Z, Chen Y-R, Zheng Y, Huang M, Vrebalov J, McQuinn R, Gapper N, Liu B, Xiang J, Shao Y and Giovannoni JJ (2013) Single-base resolution methylomes of tomato fruit development reveal epigenome modifications associated with ripening. Nature Biotechnology 31: 154-159. 